\title{
Nasser Said Al-Jahwari, Derek Kennet, Seth Priestman, Eberhard Sauer. "Fulayj: a Late Sasanian Fort on the Arabian Coast"
}

\section{Parsa Ghasemi}

\section{(2) OpenEdition Journals}

Electronic version

URL: http://journals.openedition.org/abstractairanica/50163

DOI: 10.4000/abstractairanica.50163

ISBN: 1961-960X

ISSN: 1961-960X

Publisher:

CNRS (UMR 7528 Mondes iraniens et indiens), Éditions de l'IFRI

Electronic reference

Parsa Ghasemi, "Nasser Said Al-Jahwari, Derek Kennet, Seth Priestman, Eberhard Sauer. "Fulayj: a Late Sasanian Fort on the Arabian Coast"', Abstracta Iranica [Online], Volume 40-41 | 2019, document 51, Online since 30 December 2019, connection on 20 April 2021. URL: http://

journals.openedition.org/abstractairanica/50163 ; DOI: https://doi.org/10.4000/abstractairanica. 50163

This text was automatically generated on 20 April 2021.

Tous droits réservés 


\title{
Nasser Said Al-Jahwari, Derek Kennet, Seth Priestman, Eberhard Sauer. "Fulayj: a Late Sasanian Fort on the Arabian Coast"
}

\author{
Parsa Ghasemi
}

\section{REFERENCES}

Nasser Said Al-Jahwari, Derek Kennet, Seth Priestman, Eberhard Sauer. "Fulayj: a Late Sasanian Fort on the Arabian Coast", Antiquity 92 (363), 2018, p. 724-41

1 The historical texts and archaeological finds demonstrate that the Oman region as an eastern part of the Arabian Peninsula was important for the Sasanians, from the early years of the empire by their activities both direct and indirect.

2 This article is the result of two archaeological excavations seasons at the Sasanian fort of Fulayj, which is located in the hinterland, about $13.5 \mathrm{~km}$ from the coast, in the north of the Batinah, and $30 \mathrm{~km}$ south of Sohar in Oman. Based on the excavations, the fort was built on a square plan measuring $30 \times 30 \mathrm{~m}$ (fig. 4) with a courtyard in the center. Around the corners, there are four solid and three-quarters shaped towers and beside the only entrance $(162 \mathrm{~cm}$ width) on the eastern side, there are also two semi-oval shaped towers (fig.6). In reference to the excavation evidence presented by the authors, the exterior principle walls had more than $2 \mathrm{~m}$ width, made of cobble stones and lime mortar. In addition, some interior partition walls were built of mud-brick were identified. Based on the Accelerator Mass Spectrometry (AMS) dating (table.1) and the Sasanian ceramics (fig. 8), the authors concluded that the Fulayj, is the only late Sasanian dated fort from Eastern Arabia which was built during the fifth/sixth centuries $\mathrm{AD}$ and it was in use until the mid-seventh century AD. They suggested that the Fulayj fort, built and manned by a professional army of Sasanian themselves, 
follows a trend in defensive architecture from Western Europe to Central Asia, rather than a specifically Sasanian or Roman military tradition" (p. 736) but architecturally it is very similar to the Buraq Tappeh fort in Gorgan-Iran.

3 The authors, believed the fort was part of a chain of forts separating the coastal plain, which has long been the main focus of agriculture and occupation or have been a staging post on an inland route intended to protect the approaches to the coastal plain and perhaps a port. Therefore, it functioned such as those chain of forts that was built in Mesopotamia (guarded approaches to the Khandagh Shapur and the Euphrates), or possibly similar to those forts were built around the Caspian Sea in the northern frontier of the Sasanian Empire (p.737).

4 This article contains a very rich discussion about the regional setting using the historical and archeological evidence, the detailed information about the Fulayj fort and its construction in this location, and Sasanian ceramic finds. It provides valuable new archaeological evidence of Sasanian organized military along with their political and economic control in Eastern Arabia. This new archaeological find will help to reconstruct the Sasanian empire's extent and presence in Arabian Peninsula.

\section{AUTHORS}

\section{PARSA GHASEMI}

Doctorant Archéologie, Université Paris-Nanterre 